

\title{
Improving soil health, weed management and nitrogen dynamics by Trifolium subterraneum cover cropping
}

Aurelio Scavo, Alessia Restuccia, Sara Lombardo, Stefania Fontanazza, Cristina Abbate, Gaetano Pandino, Umberto Anastasi, Andrea Onofri, Giovanni Mauromicale

\section{To cite this version:}

Aurelio Scavo, Alessia Restuccia, Sara Lombardo, Stefania Fontanazza, Cristina Abbate, et al.. Improving soil health, weed management and nitrogen dynamics by Trifolium subterraneum cover cropping. Agronomy for Sustainable Development, 2020, 40 (3), pp.18. 10.1007/s13593-020-00621-8 . hal-03227117

\section{HAL Id: hal-03227117 \\ https://hal.science/hal-03227117}

Submitted on 17 May 2021

HAL is a multi-disciplinary open access archive for the deposit and dissemination of scientific research documents, whether they are published or not. The documents may come from teaching and research institutions in France or abroad, or from public or private research centers.
L'archive ouverte pluridisciplinaire HAL, est destinée au dépôt et à la diffusion de documents scientifiques de niveau recherche, publiés ou non, émanant des établissements d'enseignement et de recherche français ou étrangers, des laboratoires publics ou privés. 


\title{
Improving soil health, weed management and nitrogen dynamics by Trifolium subterraneum cover cropping
}

\author{
Aurelio Scavo ${ }^{1}$ (1) - Alessia Restuccia ${ }^{1} \cdot$ Sara Lombardo $^{1} \cdot$ Stefania Fontanazza ${ }^{1}$. Cristina Abbate ${ }^{1} \cdot$ Gaetano Pandino $^{1}$. \\ Umberto Anastasi ${ }^{1} \cdot$ Andrea Onofri $^{2} \cdot$ Giovanni Mauromicale $^{1}$
}

Accepted: 13 April 2020 / Published online: 12 May 2020

(C) INRAE and Springer-Verlag France SAS, part of Springer Nature 2020

\begin{abstract}
The low organic matter and nitrogen levels in the soils, as well as the high weed pressure, typical of Mediterranean agroecosystems, necessitate a valid and sustainable alternative management. The utilization of cover crops such as Trifolium subterraneum L. may represent an innovative and efficient option for low-input and organic agricultural systems. In a 3-year experiment, we evaluated the effect of T. subterraneum and spontaneous flora cover cropping, with or without burying dead mulch into the soil, on the quali-quantitative composition of the weed seed bank in an apricot orchard. Moreover, the bacteria Nitrosomonas europaea and Azotobacter vinelandii, involved in the soil $\mathrm{N}$ cycle, and the content of ammoniacal and nitric soil nitrogen were quantified. For the first time, we demonstrated that $T$. subterraneum cover cropping with the incorporation of dead mulches into the soil on the one hand reduced weed biodiversity and the seed bank size ( $-70 \%$ compared to conventional management following the standard commercial practices), while, on the other hand, increased the amount of $N$. europaea (+ $109 \%)$, A. vinelandii $(+145 \%), \mathrm{NH}_{4}{ }^{+}(+137 \%)$ and $\mathrm{NO}_{3}{ }^{-}(+478 \%)$ in the soil. This approach was therefore found to be a major improvement in low-input agriculture and organic farming, and it can be applied in Mediterranean orchards as an eco-friendly strategy with the aim of reducing synthetic herbicides for weed control and mineral nitrogen fertilizers as the sole source of nitrogen supply.
\end{abstract}

Keywords Cover cropping · Trifolium subterraneum L. · Agroecosystem · Weed control · Seed bank · Real-time PCR · Soil microorganisms $\cdot$ Soil nitrogen $\cdot$ Sustainability

\section{Introduction}

The increasing intensification of agriculture over the last decades has led to serious concerns related mainly to the depletion of soil organic matter and biodiversity, as well as the increase of soil erosion, nitrate leaching and agrochemicals utilization, which have determined a negative impact on the ecosystem (Scopel et al. 2013). This scenario is particularly notable in specialized orchards, especially in Mediterranean areas where low and irregular rainfalls require frequent soil

Umberto Anastasi

umberto.anastasi@unict.it

Andrea Onofri

andrea.onofri@unipg.it

Giovanni Mauromicale

g.mauromicale@unict.it

1 Department of Agriculture, Food and Environment (Di3A), University of Catania, via Valdisavoia, 5, 95123 Catania, Italy

2 Department of Agricultural, Food and Environmental Sciences, University of Perugia, B.Go XX Giugno, 74, 06121 Perugia, Italy

Gaetano Pandino

g.pandino@unict.it 
tillage and use of herbicides to reduce moisture losses and for weed control. Furthermore, the high summer temperatures and soil oxygen levels of agricultural soils of the Mediterranean Basin promote the processes of eremacausis and contribute to soil organic matter losses. In this context, both the agricultural policy and the scientific community are looking for alternative and sustainable agronomic practices in agroecosystems. Zero or reduced tillage systems have been indicated as environmental-friendly tools for farmers, but at the same time, they are often associated with high weed pressures (Bàrberi 2002). In recent years, a valid option has been offered by cover cropping, namely the mono- or intercropping of herbaceous plants either for part of or an entire year with the aim of enhancing yields (Mauromicale et al. 2010). Cover crops exert significant positive effects on physical, chemical and biological soil characteristics, since they enhance soil organic matter and structure while reducing soil erosion and nutrient leaching, increase soil microbial activities and reduce pest and weed pressure on cash crops (Mauro et al. 2015; Mauromicale et al. 2010). Moreover, they can be integrated into conservative agricultural systems such as zero tillage to further reduce weed infestations (Samarajeewa et al. 2006). Cover crops can act as living mulches by increasing the competition with weeds for space, light and nutrients, as well as dead mulches on the soil surface by preventing seedling emergence both physically and chemically through the release of phytotoxic compounds (Teasdale and Mohler 2000).

Herbaceous species such as Trifolium spp. and other Fabaceae (Mauro et al. 2015; Sánchez et al. 2007), Sinapis alba L. and Achillea millefolium L. (Bone et al. 2009) have been used as cover crops in fruit orchards. Recently, several cereals like Avena sativa L., Secale cereale L. and Sorghum bicolor (L.) Moench., or other plant species such as Diplotaxis tenuifolia (L.) DC., Brassica nigra (L.) Koch and Mucuna pruriens (L.) DC., have been proposed, especially in organic farming, for their allelopathic properties, since they are able to release allelochemicals into the soil through root exudation or leaching from plant residues (Finney and Creamer 2008). Subterranean clovers represent the most advisable Fabaceae species for cover cropping in Mediterranean agroecosystems, where soils are generally characterized by low contents of both organic matter and nitrogen, thanks to their self-reseed and $\mathrm{N}$-fixation ability (Mauromicale et al. 2010). The meteorological trend of the Mediterranean Basin characterized by hot and dry summers followed by autumn torrential rains, together with the severe phenomena of water erosion, contributes to aggravating the low nitrogen levels of soils. This is particularly negative in organic farming, where the problem is being amplified due to the modest application of mineral nitrogen fertilizers. Within Fabaceae species commonly adopted for cover cropping, the Trifolium genus, mainly represented by $T$. subterraneum, $T$. brachycalycinum and T. pratense, is the most widespread due to its high rusticity, rapid growth and allelopathic activity on weeds (Enache and Ilnicki 1990). Suggested allelochemicals involved in subterranean clovers phytotoxicity are phenols and isoflavonoids (Liu et al. 2013). Nevertheless, subterranean clovers have been indicated to adapt well in Mediterranean orchards, where the high tree densities reduce the levels of radiation (Mauro et al. 2011; Mauromicale et al. 2010).

The analysis of long-period effects of cover crops on the weed seed bank size and composition represents one of the most important aspects indicating cover cropping efficacy on weed management (Moonen and Bàrberi 2004). The reduction of the weed seed bank with an ecological method like cover cropping is an important sustainable tool in low-input agriculture, especially under an Integrated Weed Management System (IWMS) (Scavo et al. 2000). Our hypothesis was that subterranean clover cover cropping on one side could decrease the size of the weed seed bank, while, on the other, increase the amount of two nitrogen soil bacteria and, as a consequence, the content of ammoniacal and nitric nitrogen. The efficacy of cover crops was tested both leaving plant residues on the soil surface and incorporating dead mulch into the soil to verify if green manuring could improve weed control and nitrogen dynamics. For this reason, the objective of this study was to investigate, for the first time, the effects of a 3-year T. subterraneum cover cropping (with and without burying dead mulch), compared with a spontaneous flora and a conventional management, on the quali-quantitative composition of the weed seed bank and different forms of soil nitrogen in an apricot (Prunus armeniaca L.) orchard. Moreover, following Stagno et al. (2008), in order to evaluate the influence of $T$. subterraneum cover cropping on the ecology of nitrogen transformation in a Mediterranean specialized orchard, the genes amoA and nifH, biomarkers used to study ammonia-oxidizing and nitrogen-fixing bacteria, respectively, were quantified by real-time PCR.

\section{Material and methods}

\subsection{Experimental site, climate and soil}

A 3-year field experiment was set up during 2015/2016, 2016/2017 and 2017/2018 growing seasons (hereafter referred to as seasons I, II and III, respectively) in central Sicily ( $37^{\circ}$ $13^{\prime} \mathrm{N}, 14^{\circ} 05^{\prime} \mathrm{E}, 290 \mathrm{~m}$ a.s.l., Italy), in an area where peach, apricot, olive and carob orchards, grape vineyards and cereals are common. The local climate is semiarid Mediterranean, with long and hot-dry summers, mild-wet winters and annual precipitations of $\sim 500 \mathrm{~mm}$, mostly concentrated from autumn to early spring. According to Rivas-Martinez bioclimatic indexes, the studied area may be classified within the upper thermo-Mediterranean bioclimatic belt, with inferior dry ombrotype. The soil is classified as Regosoil that, at the start 
of the experiment, was assessed as being composed of $25.7 \%$ sand, $30.6 \%$ silt and $43.7 \%$ clay, organic matter $1.9 \%$, $\mathrm{pH} 8$, total nitrogen $1.1 \%$, assimilable $\mathrm{P}_{2} \mathrm{O}_{5} 13 \mathrm{mg} \mathrm{kg}^{-1}$ and exchangeable $\mathrm{K}_{2} \mathrm{O} 422 \mathrm{mg} \mathrm{kg}^{-1}$.

\subsection{Experimental design and crop management}

In order to evaluate the effect of cover cropping on the weed seed bank, floristic composition and soil $\mathrm{N}$ ecology, a randomized block design with four replicates involving five treatments, three growing seasons and two sampling times for each season was developed. Treatments under study were as follows: (1) T. subterraneum cover cropping leaving dead mulch on the soil surface (TCC-S); (2) T. subterraneum cover cropping burying dead mulch in the soil (TCC-B); (3) spontaneous flora cover cropping leaving dead mulch on the soil surface (SCC-S); (4) spontaneous flora cover cropping burying dead mulch in the soil (SCC-B); (5) a conventional management $(\mathrm{CM})$ of apricot orchard, following the standard commercial practices (winter disc ploughing at $0.15 \mathrm{~cm}$ followed by three shallow chopping per year for weed control), as control. A net plot size of $348 \mathrm{~m}^{2}$ for each treatment was used, for a total of 20 plots of $10 \times 8.7 \mathrm{~m}$. The width of borders between treatments was $2 \mathrm{~m}$.

Apricot cv. Wonder, together with the two pollinators 'Pinkcot®' and 'Big Red®', were planted in January 2012 using a $3.5 \times 4.5-\mathrm{m}$ layout. In TCC-S and TCC-B, T. subterraneum cv. Seaton Park, a common Australian early-mid season genotype, was hand-seeded on 21 November 2015 at the rate of 2000 germinable seeds $\mathrm{m}^{-2}$ at $2-3 \mathrm{~cm}$ depth. It is a temperate annual legume with autumnwinter-spring cycle, requiring increasing daylength and vernalization requirement for flowering ( $\sim 160-180$ days). The choice of T. subterraneum is due to the low cost of seeds and the high adaptability in Mediterranean agroecosystems (Mauro et al. 2011; Mauromicale et al. 2010). Its regrowth and biomass were homogeneous both for season II and III (554.5 and $470.9 \mathrm{~g} \mathrm{~m}^{-2}$ of dry matter, respectively). Prior to seeding, the soil was subjected to shallow hoeing $(0.10 \mathrm{~m}$ deep) followed by rigid tine harrowing and fertilized with $40 \mathrm{~kg} \mathrm{ha}^{-1} \mathrm{P}_{2} \mathrm{O}_{5}, 14 \mathrm{~kg} \mathrm{ha}^{-1} \mathrm{~N}$ and $10 \mathrm{~kg} \mathrm{ha}^{-1} \mathrm{~K}_{2} \mathrm{O}$. Since the site has a history of Trifolium spp. cultivation, no Rhizobium supplement was applied. To promote germination, the plots were irrigated to field capacity. In December 2016, $1500 \mathrm{~kg} \mathrm{ha}^{-1}$ of pelleted chicken manure was applied to all plots. From the developing fruit phase until harvesting, for each season, the following soluble fertilizers were given through fertirrigation: $300 \mathrm{~kg} \mathrm{ha}^{-1}$ Ponimag® $(11 \% \mathrm{~N}, 41 \%$ $\mathrm{K}_{2} \mathrm{O}$ and $\left.3 \% \mathrm{MgO}\right), 100 \mathrm{~kg} \mathrm{ha}^{-1}$ liquid $\mathrm{Ca}$ and $50 \mathrm{~kg} \mathrm{ha}^{-1}$ Hergoton Plus ${ }^{\circledR}(8 \%$ total organic N, 26\% biologic $\mathrm{C}$ and $44.45 \%$ total organic matter). Self-compensating drip irrigation was carried out when the accumulated daily evaporation reached $40 \mathrm{~mm}$, replacing $100 \%$ of the maximum evapotranspiration. In both TCC-B and SCC-B, plant residues were incorporated into the soil by disc ploughing. Weeds were mechanically controlled by chopping twice (early spring and mid-summer) a year. The plots were kept fungal- and insectfree by spraying at low doses captano, tebuconazole and propiconazole in January-February and lambda-cyhalothrin when required.

\subsection{Meteorological conditions}

Air temperatures (minimum, maximum and mean) and rainfall were recorded once a day for seasons I, II and III with a meteorological station (Mod. Multirecorder 2.40; ETG, Firenze, Italy) sited $\sim 15 \mathrm{~m}$ from the experimental field. Both maximum and minimum monthly average temperatures and total monthly rainfall were calculated (Fig. 1). In all seasons, mean air temperatures followed the typical trend of the Mediterranean climate, with an increase in spring-summer and lowest values between December and February. In particular, season II was the hottest, with mean air temperatures of $27^{\circ} \mathrm{C}$ in July and $28.8^{\circ} \mathrm{C}$ in August. Season II experienced a particularly dry summer, with only $12.2 \mathrm{~mm}$ of rainfall out of $478 \mathrm{~mm}$ between May and August. Season III was rather unusual, in that the total rainfall was higher $(668 \mathrm{~mm})$ than the normal trend of the zone, of which $16 \%$ fell in February and $28 \%$ in October. Among the $448 \mathrm{~mm}$ of total rainfall occurring during season I, the highest levels were in March $(72.8 \mathrm{~mm})$ and November $(73.2 \mathrm{~mm})$, while the lowest one was in July $(0.2 \mathrm{~mm})$. Minimum temperature never fell below $3{ }^{\circ} \mathrm{C}$ for all three seasons, while the mean maxima were above $24.4{ }^{\circ} \mathrm{C}$ at the emergence (October) and $22.4{ }^{\circ} \mathrm{C}$ during flowering (April), thus within the optimal range for subterranean clover growth (Mauromicale et al. 2010).

\subsection{Analysis of soil seed bank}

In order to assess the effect of subterranean clover at flowering and its cumulative effect on soil seed bank, as well as to intercept both spring-summer and autumn-winter weed species, soil samples were taken twice (April $\left(\mathrm{T}_{1}\right)$ and September $\left(\mathrm{T}_{2}\right)$ ) per season. Collection of soil samples was carried out at $0-15 \mathrm{~cm}$ depth, excluding the outer $3 \mathrm{~m}$ of each plot and the non-homogeneous areas, by using a 4cm-diameter steel probe, in accordance with Restuccia et al. (2019) and Scavo et al. (2019a). Such soil depth was chosen because in fruit orchards, where soil inversion is rarely carried out, almost all of the total weed seeds is found between 0 and $15 \mathrm{~cm}$ soil depth. Each soil sample was a composite of five soil cores per plot (each of $\left.0.75 \mathrm{dm}^{3}\right)$, giving a total of 600 soil cores $(20$ plots $\times 3$ seasons $\times 2$ sampling times $\times 5$ cores) collected along the diagonals of the central part of each sampling area. This sampling design, together with a scouting of the whole 
Fig. 1 a View of the experimental station in central Sicily $\left(7^{\circ} 13^{\prime} \mathrm{N}\right.$, $14^{\circ} 05^{\prime} \mathrm{E}, 290 \mathrm{~m}$ a.s.l., Italy) on January 2016 and detail of the Trifolium subterraneum L. cover cropping on March 2017 (b). Total rainfall and average monthly maximum and minimum temperatures during season I (2015-2016) (c), II (2016-2017) (d) and III (2017-2018) (e)
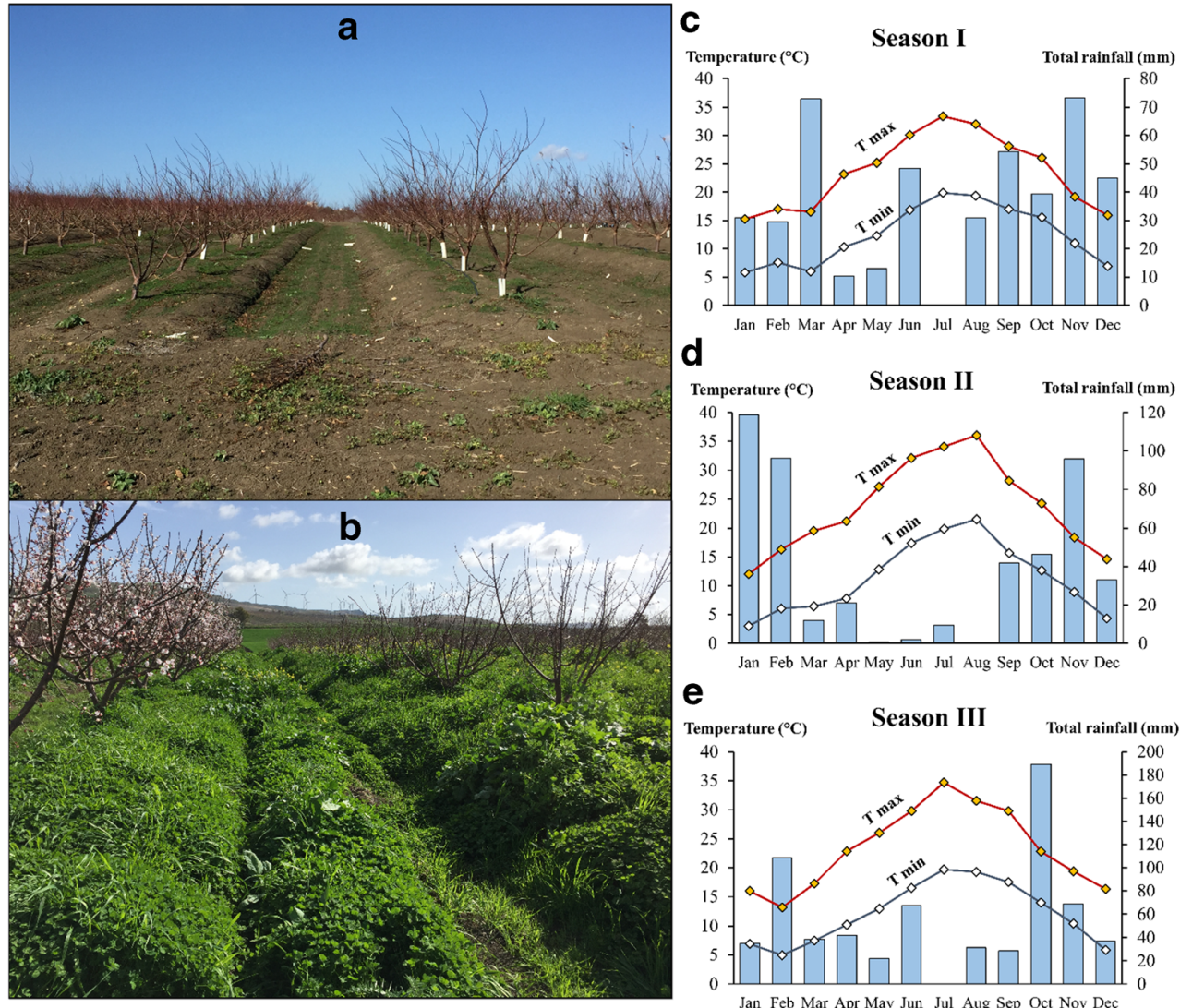

field to visually assess the weed spatial distribution and locate the sampling units, allowed a representative and homogeneous sampling. Prior to seed bank analysis, soil samples were stored in paper bags for a few days at $4{ }^{\circ} \mathrm{C}$ in the dark to prevent seed germination. In the laboratory, 20 soil cores from each treatment ( 5 cores $\times 4$ replicates) were mixed well giving a final volume of $3 \mathrm{dm}^{3}$ and the inert fraction (stones, pebbles, etc.) was hand-removed. For the seedbank analysis, four subsamples of $150 \mathrm{~g}$ for each treatment were used. Each subsample was pre-treated with $5 \mathrm{~g}$ of sodium hexametaphosphate solution for $20 \mathrm{~min}$ to disperse the colloid matrix and facilitate the subsequent washing. Seed extraction was done by putting soil samples into a metal tube with a removable cap fitted with steel mesh of $250 \mu \mathrm{m}$, using an electric adjustable pressure (20-120 bar max) washer (Karcher, K 3500 model, Winnenden, Germany). The extracted fraction was then placed inside Petri dishes, air-dried for $24 \mathrm{~h}$, handseparated from inert particles, identified and counted. Seed identification was based on the botanical family by means of a MS5 Leica stereomicroscope (Leica Microsystems, Wetzlar, Germany), and the nomenclature of each species was given following Pignatti (1982). The seed bank size was expressed as the number of seeds per square metre of surface area for each plot (Scavo et al. 2019a).

\subsection{Soil molecular analyses}

Soil molecular analyses were performed in triplicate on soil samples collected at $0-15 \mathrm{~cm}$ depth for the five treatments under study, twice (March $\left(T_{1}\right)$ and June $\left(T_{2}\right)$ ) for each season. The different sampling times with respect to the soil seed bank were due to the need to monitor soil microflora under different environmental factors and to understand if it is subjected to seasonal variation. The extraction of soil DNA was carried out following Scavo et al. (2019a).

\subsubsection{Real-time quantitative PCR assay of soil DNA extracts}

Real-time PCR is a powerful technique to determine the amount of PCR product. The absolute quantification method was used to analyse data from real-time quantitative PCR experiments. Absolute quantification determines the input copy number of the gene of interest, usually by relating the PCR signal to a standard curve (Livack and Schmittgen 2001). A DNA-binding dye, such as SYBR Green, binds to all double-stranded DNA in PCR, causing fluorescence of the dye. An increase in DNA product during PCR therefore leads to an increase in fluorescence intensity and is measured at each cycle, thus allowing DNA concentrations to be quantified. In real-time PCR assay, a positive reaction is detected by accumulation of a fluorescent signal. The $\mathrm{Ct}$ (cycle threshold) 
is defined as the number of cycles required for the fluorescent signal to cross the threshold (i.e. exceeds background level). $\mathrm{Ct}$ levels are inversely proportional to the amount of target nucleic acid in the sample.

In this study, an iCycler $\mathrm{iQ}^{\mathrm{TM}_{5}}$ (Bio-Rad) detection system was used. The genes amoA and nifH were amplified using the following primer sets: A189 (GGH GAC TGG GAY TTC TGG) and amoA-2R (CCT CKG SAA AGC CTT CTTC) as described by Okano et al. (2004) and nifH11 (GAY CCN AAR GCN GAC TC) and nifH22 (ADW GCC ATC ATY TCR CC) as described by Yeager et al. (2004), respectively. For amoA gene, PCR amplification conditions, using SYBR GREEN technology, were as follows: (1) $2 \mathrm{~m}$ at $50{ }^{\circ} \mathrm{C}$, (2) $10 \mathrm{~m}$ at $95{ }^{\circ} \mathrm{C}$, (3) 40 cycles of $45 \mathrm{~s}$ at $95{ }^{\circ} \mathrm{C}$, (4) $1 \mathrm{~m}$ at $55{ }^{\circ} \mathrm{C}$ and (5) $45 \mathrm{~s}$ at $72{ }^{\circ} \mathrm{C}$. Reactions were $25-\mu \mathrm{l}$ volumes using Platinum Quantitative PCR Supermix-UDG (Invitrogen). For testing the primers, Nitrosomonas europaea (ATCC 19718) was directly used as a source of DNA template in a $25-\mu 1$ reaction. For nifH gene, PCR amplification conditions were as follows: (1) $5 \mathrm{~m}$ at $95^{\circ} \mathrm{C}$, (2) 20 cycles of $1 \mathrm{~m}$ at $48{ }^{\circ} \mathrm{C}$, (3) $1 \mathrm{~m}$ at $72{ }^{\circ} \mathrm{C}$, (4) $45 \mathrm{~s}$ at $94{ }^{\circ} \mathrm{C}$ and (5) $10 \mathrm{~m}$ at $72{ }^{\circ} \mathrm{C}$. For testing the primers, Azotobacter vinelandii (ATCC 12518) was used. The same strains were used as a standard for calibration curves and the subsequent calculation of their amount. Standard curves were derived using known amounts of DNA corresponding to $0.001-100 \mathrm{ng}$ of genomic DNA. Threshold cycle $(\mathrm{Ct})$ values were determined, in triplicate, using $2-\mu \mathrm{l} \mathrm{sam-}$ ples of each soil DNA extract per PCR reaction. Ct values were converted to nanograms of DNA using the equation derived from the standard curves.

\subsubsection{Soil N quantification}

To determine the extractable $\mathrm{N}, 10 \mathrm{~g}$ of soil samples was transferred into $250-\mathrm{ml}$ bottles with $50 \mathrm{ml}$ of $0.5 \mathrm{M} \mathrm{K}_{2} \mathrm{SO}_{4}$. The suspensions were then shaken for $1 \mathrm{~h}$, end-over-end, filtered through glass fibre Whatman GF/A and $0.45-\mu \mathrm{m}$ Millipore filters and finally centrifuged for $15 \mathrm{~min}$ at $3000 \mathrm{rpm}$. The concentrations of $\mathrm{NH}_{4}{ }^{+}$and $\mathrm{NO}_{3}{ }^{-}$in the extracts were colorimetrically measured by diffusion (Bremner 1965; Crooke and Simpson 1971).

\subsection{Data and statistical analysis}

The analysis of variance (ANOVA) was used to analyse the data, according to a three-way factorial model with '5 cover cropping', ' 3 seasons' and '2 sampling times' as the main factors. Before ANOVA, the basic assumptions of homoscedasticity and normality were tested through a graphical inspection of the residuals together with the Bartlett's test for homoscedasticity. Data about seed bank size and PCR values were log-transformed prior to analyses to remedy deviations from basic assumptions (untransformed data are presented and discussed). Values were reported as means \pm standard deviation and Tukey's HSD test with $\alpha=0.05$ was used for pairwise mean comparisons.

The analysis of the weed seed bank composition was carried out estimating species abundance and diversity. Abundance, i.e. the measure of the number or frequency of individuals in an area, was measured taking into account the relative density (RD) and the relative frequency (RF). RD was calculated as the number of seeds for a given weed species divided by the total number of weeds within the plot and RF as the absolute frequency of one species (i.e. the proportion of sampling cores in which the species was found per plot) divided by the sum of absolute frequencies of all species. Following Derksen et al. (1993), the Relative Abundance Index $[\mathrm{RAI}=(\mathrm{RD}+\mathrm{RF}) / 2]$ was used for single major weeds and data were arcsin-square root transformed prior to analysis. This parameter involves both the density and the evenness of weed communities, by downweighting the species very abundant in few samples and increasing the importance of species present in many samples but at a low density. However, ANOVA showed no significance for main factors and their interactions, and, for this reason, RAI data were not included in the results. In accordance with Travlos et al. (2018), species diversity was described considering the weed species richness and their evenness within community ( $\alpha$-diversity). The former refers to the total number of species counted in the five soil cores for each plot, as suggested by Moonen and Bàrberi (2004). This data did not show any violation of basic assumptions, and, therefore, it was not transformed prior to ANOVA. Following Adeux et al. (2019), the species evenness was estimated with the Shannon diversity index $(\mathrm{H})$ and Pielou's evenness index (J), both computed as in Travlos et al. (2018). To meet the basic assumptions for linear models, $\mathrm{H}$ data were square root transformed, while a logit transformation was applied to $\mathrm{J}$ data (Adeux et al. 2019). Values of zero were attributed to monospecific weed communities.

Data about the composition of weed seed bank were analysed by multivariate techniques. The effects of the three factors under study (cover cropping, season and sampling time) and their interactions were tested by a permutational (999 permutations) analysis of variance (PERMANOVA; Anderson 2001) based on Euclidean distances. In order to visualize these effects, principal component analyses (PCA) on the covariance matrix were performed for each season, considering the means for each 'treatment $\times$ sampling time' combination. The results of 
the ordination were displayed on 'distance' biplots (Legendre and Legendre 2012).

\section{Results and discussion}

\subsection{Weed density and species composition}

The 0-15-cm soil seed bank was composed of a total of 22 weed species or genera, $86 \%$ of which were annuals and $14 \%$ perennials (Table 1). Among the 14 families, the Asteraceae was the most represented (43\%), followed by Brassicaceae (14\%), Poaceae (14\%) and Polygonaceae (14\%). Regarding the biological groups, $87 \%$ were therophytes, $9 \%$ geophytes and $4 \%$ hemicryptophytes. A similar scenario was found in Sicily by Restuccia et al. (2019). Except for season II, the incorporation of subterranean clover mulches into the soil reduced weed biodiversity compared to $\mathrm{CM}$, with a general trend TCC-B $\leq \mathrm{TCC}-\mathrm{S} \leq \mathrm{SCC}-\mathrm{S} \leq \mathrm{SCC}-\mathrm{B} \leq \mathrm{CM}$. In particular, the number of weed species per square metre was 2.5, 3.5, 4.5, 7 and 7.5 for TCC-B, SCC-S, TCC-S, CM and SCC-B, respectively, in season I $(p \leq 0.05, \mathrm{SED}=1.06)$, and $4,5.5,5.5$,
7 and 7.5 for TCC-B, TCC-S, SCC-S, CM and SCC-B, respectively, in season II $(p \leq 0.05, \mathrm{SED}=1.55)$. However, any interaction between main factors was significant for $p \leq 0.05$. The reduction in weed species richness caused by cover crops has been reported by other authors (Moonen and Bàrberi 2004; Isik et al. 2009). On the contrary, Ngouajio et al. (2003) and Swanton et al. (1999) indicated that the influence of cover cropping on weed species number was not significant. The few differences between treatments under study in terms of weed species number could be explained by the socalled buffering effect of the weed seed bank, which means that the effects of agronomic practices (tillage, cover cropping, crop rotation, etc.) on the real weed flora in agroecosystems are not immediate due to the high longevity of weed seeds. Although the reduction of weed species number is an important aspect in weed management, the effect of cover cropping on the weed seed bank composition should be not considered only in terms of species richness. In addition to such parameter, weed species composition was analysed by estimating their diversity (H; Fig. 2a) and evenness (J; Fig. 2b) within community. Both $\mathrm{H}$ and $\mathrm{J}$ showed similar results, with the three-way interaction significant at $p \leq 0.001$ and 'sampling

Table 1 Botanical family, biological and ecophysiological groups, life cycle, relative density (RD) and relative frequency (RF) of the weed species from the total soil seed bank $(0-15 \mathrm{~cm})$ among 5 cropping systems, 2 seasons and 3 sampling times

\begin{tabular}{|c|c|c|c|c|c|c|}
\hline Weed species & Botanical family & Biological group & Ecophysiological group & Life cycle & $\mathrm{RD}(\%) *$ & $\mathrm{RF}(\%)^{*}$ \\
\hline Amaranthus retroflexus $\mathrm{L}$. & Amaranthaceae & $\mathrm{Th}$ & $\mathrm{Su}$ & Annual & 5.6 & 76.4 \\
\hline Anagallis arvensis $\mathrm{L}$. & Primulaceae & Th & $\mathrm{Au}-\mathrm{Wi}$ & Annual & 18.4 & 95.1 \\
\hline Borago officinalis L. & Boraginaceae & Th & $\mathrm{Sp}-\mathrm{Su}$ & Annual & 1.6 & 60.2 \\
\hline Centaurea napifolia $\mathrm{L}$. & Asteraceae & Th & $\mathrm{Su}$ & Annual & 2.5 & 44.0 \\
\hline Cichorium intybus $\mathrm{L}$. & Asteraceae & $\mathrm{Hr}$ & Ind & Perennial & 1.3 & 15.3 \\
\hline Cirsium arvense (L.) Scop. & Asteraceae & G & $\mathrm{Su}$ & Perennial & 2.0 & 47.1 \\
\hline Euphorbia prostrata Aiton & Euphorbiaceae & $\mathrm{Th}$ & $\mathrm{Su}-\mathrm{Au}$ & Annual & 0.5 & 8.7 \\
\hline Fallopia convolvulus (L.) Á. Löve & Polygonaceae & Th & $\mathrm{Sp}-\mathrm{Su}$ & Annual & 0.9 & 53.4 \\
\hline Fumaria sp. & Fumariaceae & Th & $\mathrm{Sp}-\mathrm{Su}-\mathrm{Au}$ & Annual & 1.0 & 38.3 \\
\hline Galium aparine $\mathrm{L}$. & Rubiaceae & $\mathrm{Th}$ & $\mathrm{Sp}-\mathrm{Su}-\mathrm{Au}$ & Annual & 1.8 & 56.4 \\
\hline Helminthotheca echioides (L.) Holub & Asteraceae & Th & $\mathrm{Su}-\mathrm{Au}$ & Annual & 3.3 & 53.6 \\
\hline Lamium amplexicaule $\mathrm{L}$. & Lamiaceae & Th & Ind & Annual & 0.4 & 24.7 \\
\hline Medicago sp. & Fabaceae & Th & $\mathrm{Au}-\mathrm{Wi}-\mathrm{Sp}$ & Perennal & 2.3 & 12.4 \\
\hline Phalaris paradoxa $\mathrm{L}$. & Poaceae & Th & $\mathrm{Sp}$ & Annual & 8.0 & 85.5 \\
\hline Polygonum aviculare L. & Polygonaceae & Th & $\mathrm{Sp}-\mathrm{Su}$ & Annual & 0.9 & 19.0 \\
\hline Portulaca oleracea L. & Portulacaceae & Th & $\mathrm{Su}$ & Annual & 8.9 & 86.6 \\
\hline Raphanus raphanistrum L. & Brassicaceae & Th & $\mathrm{Sp}$ & Annual & 0.1 & 20.2 \\
\hline Senecio vulgaris L. & Asteraceae & Th & Ind & Annual & 0.3 & 12.2 \\
\hline Setaria viridis (L.) P.Beauv. & Poaceae & $\mathrm{Th}$ & $\mathrm{Su}$ & Annual & 1.1 & 28.6 \\
\hline Sinapis arvensis L. & Brassicaceae & Th & $\mathrm{Sp}$ & Annual & 8.7 & 81.7 \\
\hline Sonchus sp. & Asteraceae & G & Ind & Annual & 24.5 & 97.4 \\
\hline Veronica sp. & Scrophulariaceae & Th & Ind & Annual & 5.8 & 50.0 \\
\hline
\end{tabular}

Th therophytes, $H r$ hemicryptophytes, $G$ geophytes, $S u, A u$, Wi, $S p$ summer, autumn, winter, spring species, In indifferent species

*Averaged over all treatments 
a



b

Pielou index $\quad \operatorname{LSD}_{(p \leq 0.05)}=0.32$

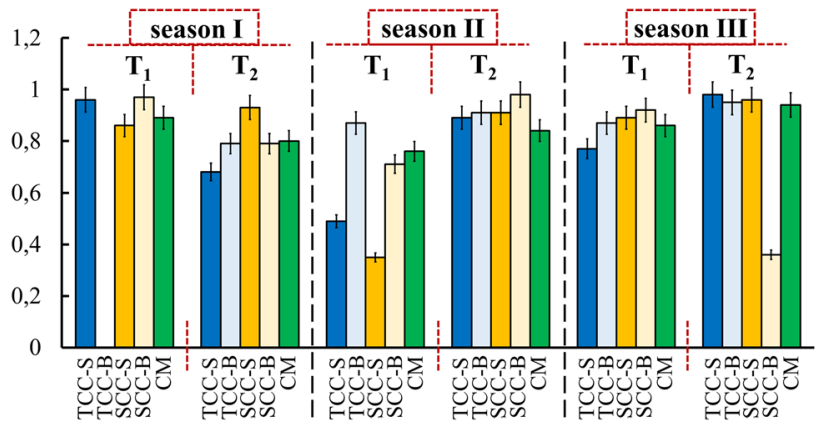

C

seed bank size $\left(\mathbf{m}^{-\mathbf{2}}\right) \quad \operatorname{LSD}_{(p \leq 0.05)}=1137.07$

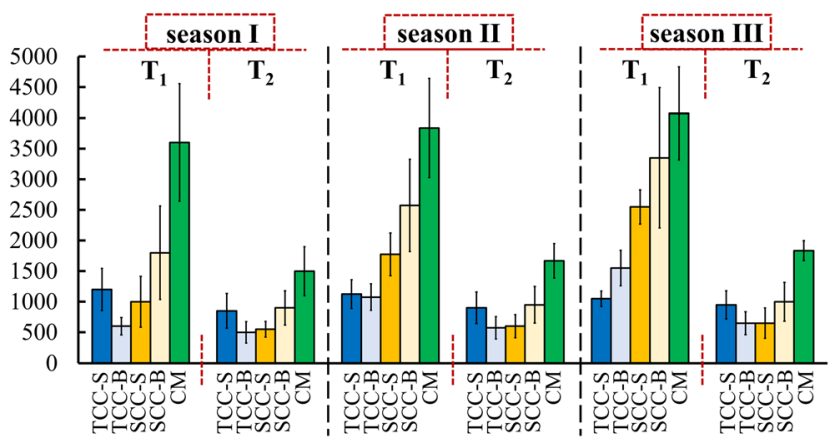

d



time' accounting for $12.5 \%$ and $23.3 \%$, respectively, to the analysis of variance (Table 2). On the average of season and sampling time, species diversity was significantly higher in
Fig. 2 Shannon diversity index (a), Pielou's evenness index (b) and number of weed seeds in the soil seed bank (c) of an apricot orchard as affected by cover cropping, season and sampling time. Effect of cover cropping on the average of seasons and sampling times (d). Each bar means \pm standard deviation. Different letters indicate statistical significance for $p \leq 0.05$. LSD interaction was calculated with the Tukey's HSD Test for $p=0.05$. TCC-B: T. subterraneum cover cropping burying dead mulch in the soil; SCC-S: spontaneous flora cover cropping leaving dead mulch on the soil surface; SCC-B: spontaneous flora cover cropping burying dead mulch in the soil; $\mathrm{CM}$ : conventional apricot management; season I: 2015/2016; season II: 2016/2017; season III: 2017/2018; $T_{1}$ : April; $T_{2}$ : September

CM and SCC-B than in TCC-S and TCC-B (1.48 and 1.49 vs. 1.27 and 1.23). Although the diversity indices are relative and serve only to compare diversity among communities, $\mathrm{H}$ values calculated in this study were lower than those commonly found in other cropping systems, while $\mathrm{J}$ data were generally high $(0.85,0.82,0.80,0.79$ and 0.73 in CM, SCC-S, TCC-S, SCC-B and TCC-B, respectively). These results indicate low weed diversity and few dominant species. The seed bank was more diverse and even at the end of the experiment $(\mathrm{H}=1.25,1.23,1.54$ and $\mathrm{J}=0.76,0.77$ and 0.85 in seasons $\mathrm{I}$, II and II, respectively), probably due to the higher availability of nitrogen in the soil (Fig. 2a, b). Furthermore, it should be taken into account that weed communities with a low biodiversity, but constituted by highly competitive species or with high densities, may negatively affect the cash crop more so than weed communities containing slightly competitive species or with low densities (Moonen and Bàrberi 2004). For that reason, the RD, RF and RAI were also analysed. The major species or genera (i.e. those contributing more than $3 \%$ to the total seed bank density and with a minimum frequency of 50\%) included 8 seed-propagated weeds: Amaranthus retroflexus L., Anagallis arvensis L., Helminthotheca echioides (L.) Holub, Phalaris paradoxa L., Portulaca oleracea L., Sinapis arvensis L., Sonchus sp. and Veronica sp. The sum of these species accounted for $83.2 \%$ of the whole $0-15 \mathrm{~cm}$ seed bank density (Table 1 ). The analysis of variance showed that the choice of cover cropping did not affect RAIs of major weed species and genera, as reported also by Swanton et al. (1999) for Secale cereale L. cover crop, while the effect of season was significant for $p \leq 0.05$ only for $A$. arvensis, $H$. echioides and P. oleracea (data not shown).

Consistently with univariate analyses, PERMANOVA showed that the specific composition of weed seed bank was significantly affected by the three-way interaction 'cover crop $\times$ sampling time $\times$ season' $(F=10.2, p \leq 0.001$; Table 2$)$. Sampling time and season explained $32.1 \%$ and $29.3 \%$, respectively, of the total variance. The results can be visualized by considering the ordination biplots from PCAs (Fig. 3), which show some interesting associations between cover crops and weed species, particularly for season II and III due to the cumulative effect of cover cropping on the soil seed 
Table $2 F$ values as absolute value of main factors and their interactions resulting from analysis of variance (ANOVA)

Source of variation

\begin{tabular}{|c|c|c|c|c|c|c|c|}
\hline & \multicolumn{3}{|l|}{ Main factors } & \multicolumn{4}{|c|}{ Interactions } \\
\hline & Cover cropping $(\mathrm{C})$ & Season (S) & Sampling time $(\mathrm{T})$ & $(\mathrm{C}) \times(\mathrm{S})$ & $(\mathrm{C}) \times(\mathrm{T})$ & $(\mathrm{S}) \times(\mathrm{T})$ & $(\mathrm{C}) \times(\mathrm{S}) \times(\mathrm{T})$ \\
\hline \multicolumn{8}{|c|}{ Seed bank biodiversity } \\
\hline Shannon index & $53.5^{* * * *}$ & $102.9 * * *$ & $103.6^{* * *}$ & $137.3 * * *$ & $100.3 * * *$ & $222.0 * * *$ & $110.6^{* * *}$ \\
\hline Pielou Index & $4.44 * *$ & $8.6^{* *}$ & $31.97 * * *$ & $26.0 * * *$ & $19.7 * * *$ & $23.4 * * *$ & $22.5 * * *$ \\
\hline \multicolumn{8}{|l|}{ Seed bank } \\
\hline Total size & $61.0 * * *$ & $43.4 * * *$ & $316.4 * * *$ & $3.1 * *$ & $2.7 *$ & $17.6^{* * *}$ & $3.3 * *$ \\
\hline Composition $^{1}$ & $25.0^{* * *}$ & $74.6^{* * *}$ & $81.6^{* * *}$ & $18.1^{* * *}$ & $16.8^{* * *}$ & $27.4^{* * *}$ & $10.2 * * *$ \\
\hline \multicolumn{8}{|l|}{ RT-PCR analysis } \\
\hline amoA & $868.9 * * *$ & $6.5^{* *}$ & $1.1 \mathrm{NS}$ & $3.3^{* *}$ & $4.9^{* *}$ & $6.3^{* *}$ & $2.4 *$ \\
\hline nifH & $1385.2 * *$ & $10.1 * * *$ & $25.8^{* * *}$ & $6.7 * * *$ & $3.7 * *$ & $0.3 \mathrm{NS}$ & $2.3 *$ \\
\hline \multicolumn{8}{|l|}{$\mathrm{N}$ soil forms } \\
\hline $\mathrm{NH}_{4}^{+}$ & $158.5^{* * *}$ & $158.3^{* * *}$ & $176.1 * * *$ & $17.2^{* * *}$ & $16.8^{* * *}$ & $56.8^{* * *}$ & $10.5 * * *$ \\
\hline $\mathrm{NO}_{3}^{-}$ & $586.8 * * *$ & $100.7 * * *$ & $40.3 * * *$ & $39.7 * * *$ & $10.0 * * *$ & $25.6^{* * *}$ & $9.1 * * *$ \\
\hline $\mathrm{N}_{\mathrm{TOT}}$ & $714.3 * * *$ & $236.1 * * *$ & $173.7 * * *$ & $54.4^{* * *}$ & $21.8 * * *$ & $58.5^{* * *}$ & $17.5^{* * *}$ \\
\hline Degrees of freedom & 4 & 2 & 1 & 8 & 4 & 2 & 8 \\
\hline
\end{tabular}

Seed bank biodiversity

Values are given as $F$ of Fisher. $* * * * *$ and $*$ indicate significant at $p \leq 0.001, p \leq 0.01$ and $p \leq 0.005$, respectively, and ${ }^{\mathrm{NS}}$, not significant

${ }^{1}$ The composition of weed seed bank was analysed by using a permutation multivariate ANOVA (Anderson 2001)

bank. If we indicate the first sampling time as $\mathrm{T}_{1}$ and the second as $\mathrm{T}_{2}$, we can see that, in season I, CM- $\mathrm{T}_{1}$ was heavily infested with $A$. retroflexus, $P$. oleracea and $H$. echioides, while the other treatments were mainly discriminated along the second $\mathrm{PC}$ axis, depending on the presence of $A$. arvensis (TCC-B-T $1>$ SCC-B-T $2>$ TCC-B-T 2 , followed by the other treatments) and P. paradoxa (in particular TCC-S- $\mathrm{T}_{2}$ ). In season II, CM- $\mathrm{T}_{1}$ was heavily infested with Sonchus sp. and $S$. arvensis, while SCC-S- $\mathrm{T}_{1}$ and TCC-S- $\mathrm{T}_{1}$ were mainly infested by Sonchus sp. and A. arvensis. TCC-B- $\mathrm{T}_{1}$ was mainly infested by $A$. arvensis while in $\mathrm{T}_{2}$ all treatments showed a lower seed bank, mainly composed by P. oleracea and A. arvensis. In season III, the discrimination of treatments is clearer, in the sense that we mainly see three groups: $\mathrm{CM}-\mathrm{T}_{1}$ on the left side, the treatment based on SCC in the rightuppermost side and the treatment based on TCC on the right-lowermost side. SCC-S- $\mathrm{T}_{2}$ represents an exception, as it was more closely related to TCC, in terms of seed bank composition. CM- $\mathrm{T}_{1}$ was mainly infested with $S$. arvensis and $A$. arvensis, while the treatments based on SCC (excluding SCC-S- $\mathrm{T}_{2}$ ) were mainly characterized by Sochus sp. On the other hand, the treatments based on TCC and SCC-S- $\mathrm{T}_{2}$ were less infested. In general, although the treatments under study caused shifts in species richness, abundance and frequency, the relationship between treatments and weed species composition appeared to be less clear, demonstrating that major weed species are able to establish independently of the treatments. On the contrary, weed associations are clearer if correlated with season and sampling time, in accordance with PERMANOVA analysis.

\subsection{Size of the soil weed seed bank}

The interaction 'cover cropping $\times$ season $\times$ sampling time' was significant for $p \leq 0.01$, although with a low $F$ value (3.3), indicating that the seed bank size varied in relation to the combination of the three factors (Table 2). However, the choice of sampling time alone explained much of the weed seed bank reduction, with a contribution of $70.7 \%$ to the analysis of variance, followed by cover cropping (13.6\%). In fact, on the average of season and cover cropping, the size of soil weed seed bank was more than two times higher in April than September (2078 vs. 938.5 seeds $^{-2}$ ), and this difference was more marked in the conventional management (3838 vs. 1668 seeds $\mathrm{m}^{-2}$ ) (Fig. 2c). Our results are corroborated by Vieira et al. (2015), who found a lower seed bank size in autumn than spring in four different subtropical grassland areas. By contrast, Felix and Owen (2001) reported an opposite trend in Iowa (USA) under a conservation reserve program. The results presented here can be explained by seed bank species composition, which was primarily composed of annual spring-summer weeds with high dormancy rate during autumn. Besides, the number of weed seeds in the soil seed bank showed a similar trend during the three seasons, probably because meteorological conditions did not substantially differ among years under study and by the fact that only 


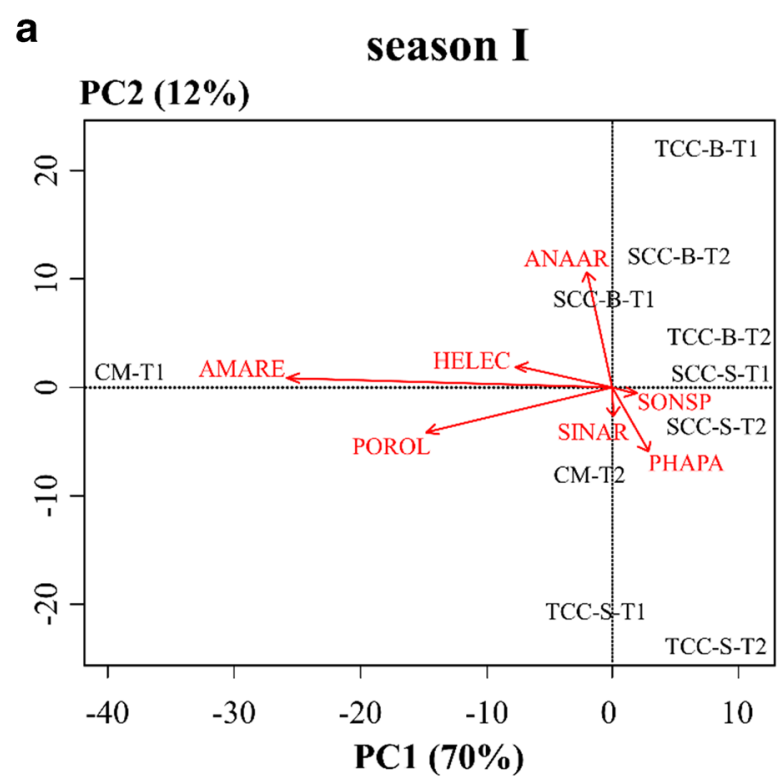

b
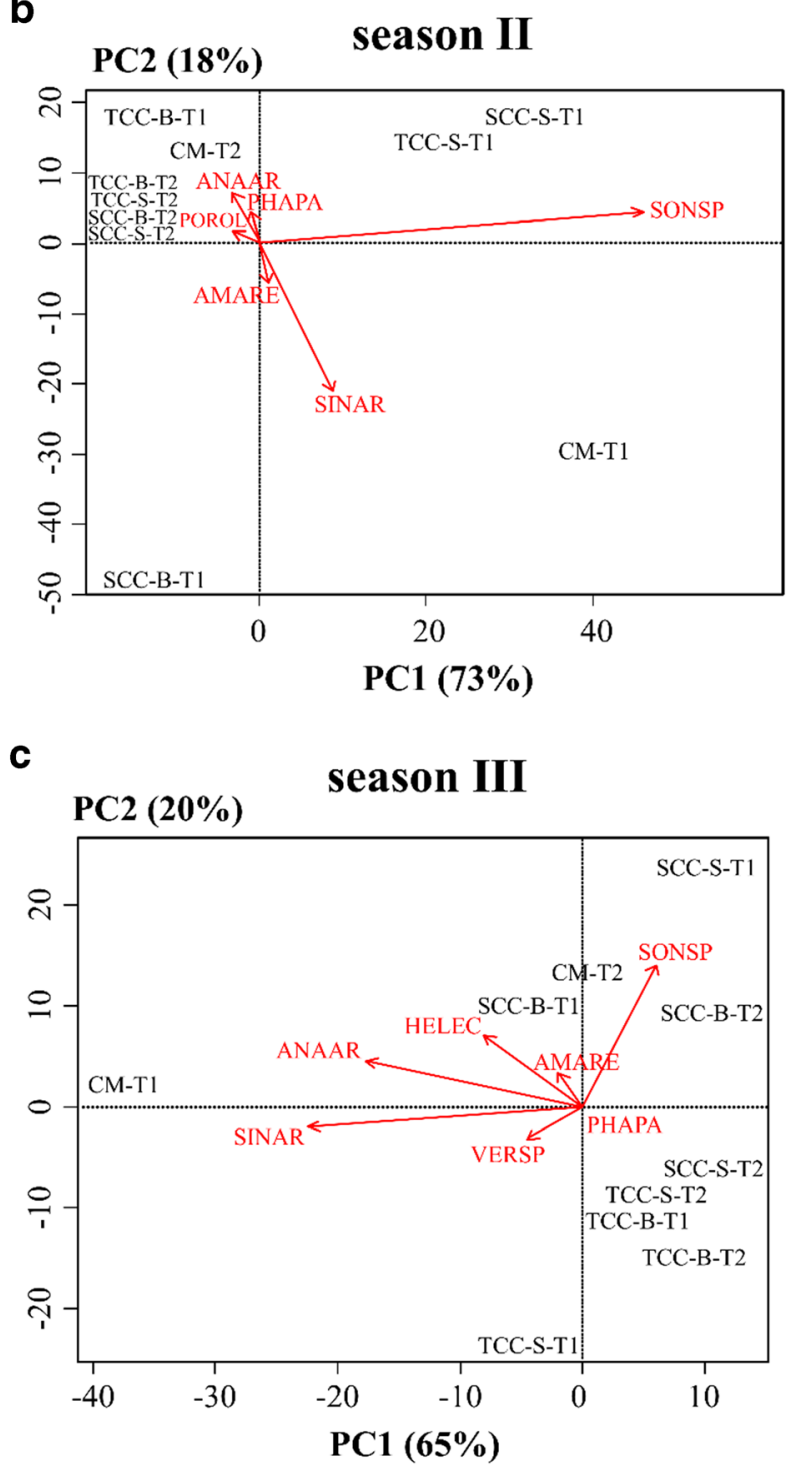

Fig. 3 Principal component analysis ordination biplots with the 8 most abundant weed species and genera in different cover cropping treatments in an apricot orchard. a Season I: 2015/2016; b season II: 2016/2017; c season III: 2017/2018; $\mathrm{T}_{1}$ : April; $\mathrm{T}_{2}$ : September; TCC-S: Trifolium subterraneum cover cropping leaving dead mulch on the soil surface; TCC-B: T. subterraneum cover cropping burying dead mulch in the soil; SCC-S: spontaneous flora cover cropping leaving dead mulch on the soil surface; SCC-B: spontaneous flora cover cropping burying dead mulch in the soil; CM: conventional apricot management; AMARE: Amaranthus retroflexus; ANAAR: Anagallis arvensis; HELEC: Helminthotheca echioides; PHAPA: Phalaris paradoxa; POROL: Portulaca oleracea; SINAR: Sinapis arvensis; SONSP: Sonchus sp.; VERSP: Veronica sp.

surface tillage with no soil inversion was applied. The effect of cover cropping significantly affected the amount of weed seeds in the soil seed bank. Regardless of season and sampling time, the seed bank size was $63 \%$ and $70 \%$ lower in TCC-S and TCC-B, respectively, than in CM (Fig. 2d). Subterranean clover cover cropping, therefore, performed better than spontaneous flora cover cropping. As reported by Lemessa and Wakjira (2014), the mechanism of weed suppression operated by cover crops can be either physical or chemical. On one hand, living cover crops prevent weed flowering by competing with them for water, nutrients, light and space, mainly for the smaller seeded species with less energy reserves; on the other hand, dead mulches that remain on the soil surface or are incorporated into the soil after cover crop senescence can inhibit seed germination, weed emergence, establishment and early growth through allelopathic effects (Scavo et al. 2018, $2019 \mathrm{a}, \mathrm{b})$. The allelopathic effects appear more correlated to the effect of T. subterraneum than spontaneous weed flora and especially after incorporation of clover resides into the soil due to the longer persistence of released allelochemicals into the soil (Ohno et al. 2000). Other mechanisms related to cover crop weed suppression are well described by Lemessa and Wakjira (2014) and Kruidhof et al. (2009). Of course, these mechanisms did not equally affect all weed species but depend on cover crop genotype, environmental and pedological conditions, on the quantity of the plant residue as well as on the rate of decomposition (Scavo et al. 2019b).

\subsection{Effect on soil $\mathrm{N}$ ecology}

With the aim of evaluating the effect of cover cropping on soil $\mathrm{N}$ ecology in an apricot orchard, the bacteria $N$. europaea and A. vinelandii, as well as the content of soil $\mathrm{NH}_{4}{ }^{+}, \mathrm{NO}_{3}{ }^{-}$and their sum $\left(\mathrm{N}_{\mathrm{TOT}}\right)$, were quantified among the five treatments, three seasons and two sampling times under study. Also in this case, the three-way interaction was significant at $p \leq 0.001$ and $p \leq 0.005$ for $\mathrm{N}$ soil forms and RT-PCR data, respectively (Table 2). However, $97.3 \%$ and $96.6 \%$ of the analysis of variance of $N$. europaea and $A$. vinelandii varied in relation to the cover cropping. The latter was the main factor also for soil 
$\mathrm{NO}_{3}{ }^{-}(72.2 \%)$ and $\mathrm{N}_{\text {TOT }}$ (56\%), highlighting how the presence and transformation of soil $\mathrm{N}$ in the apricot orchard depended almost exclusively on the type of cover cropping adopted. As observed for seed bank size, T. subterraneum cover cropping significantly increased the amount of the bacteria N. europaea (Fig. 4a) and A. vinelandii (Fig. 4b) and the quantity of $\mathrm{NH}_{4}{ }^{+}$(Fig. 4c), $\mathrm{NO}_{3}{ }^{-}$(Fig. 4d) and $\mathrm{N}_{\mathrm{TOT}}$ (Fig. 4e) in soil samples. In particular, the RT-PCR analysis showed $\mathrm{Ct}$ values between 10 and 14 in the presence of T. subterraneum, higher levels (17-21) with spontaneous flora cover cropping and much higher values (25-28) with conventional management. Given that $\mathrm{Ct}$ levels are inversely proportional to the amount of target nucleic acid in the sample, the obtained data demonstrate a higher presence of the bacteria $N$. europaea and A. vinelandii in T. subterraneum cover cropping. This trend remained almost constant among seasons and sampling times, showing that climatic conditions did not affect the amount of amo $A$ and nifH genes. Also, the incorporation of mulches into the soil did not show any significant effect. Regarding the $\mathrm{N}$ soil forms, on the average of seasons and sampling times, $\mathrm{NO}_{3}{ }^{-}$values ranged from 18.5 (TCC-B) to $5.4 \mathrm{ppm}(\mathrm{CM})$ and $\mathrm{NH}_{4}{ }^{+}$ones from 8.1 (TCC-S) to $3.2 \mathrm{ppm}$ (CM) (Fig. $4 \mathrm{c}, \mathrm{d})$. This positive effect became stronger, mainly for $\mathrm{NH}_{4}{ }^{+}$and $\mathrm{N}_{\text {TOT }}$, in the June sampling $\left(\mathrm{T}_{2}\right)$ of season III as a result of a cumulative effect, due to the low mobility of ammoniacal nitrogen in the clay soil. In fact, the highest $\mathrm{NH}_{4}{ }^{+}$ levels were detected in the $\mathrm{T}_{2}$ sampling of season III under TCC-S and TCC-B (16.8 and $13.8 \mathrm{ppm})$, with an increase of +223.1 and $126.3 \%$, respectively, compared to the same treatments in season I. These results are probably associated with weed flora composition, which was more diverse and even in the last experimental season and in presence of T. subterraneum cover cropping, seeming due to the higher availability of nitrogen, although RAIs of major weed species and genera were not significant for main factors and interactions, indicating that weed abundance did not differ significantly. Moreover, despite the higher presence of both nitrogen bacteria and mineral forms in TCC treatments, PCAs showed a weak relationship between weed species and nitrogen indicators. The increase of soil $\mathrm{NH}_{4}{ }^{+}$and $\mathrm{NO}_{3}{ }^{-}$is attributable not only to the $\mathrm{N}$-fixation ability of subterranean clover but also to the stimulation of $N$. europaea and A. vinelandii biomass, especially the latter, being an $\mathrm{N}$-fixing bacterium. Although the effect of cover cropping on $N$. europaea and A. vinelandii has never been studied, the beneficial role of cover crops on soil microorganisms is well documented (Martínez-García et al. 2018; Nair and Ngouajio 2012; Stagno et al. 2008). In this study, the increase of amoA and nifH genes due to spontaneous flora, and mainly $T$. subterraneum cover cropping, can be attributed both to a direct and indirect effect: on one hand, soil microorganisms take direct advantage of the high quantity of carbon-containing compounds and phytohormones released by living plant roots into the rhizosphere; on a $\operatorname{amo} A$

Cycle threshold $(\mathrm{Ct}) \quad \operatorname{LSD}_{(p \leq 0.05)}=2.21$

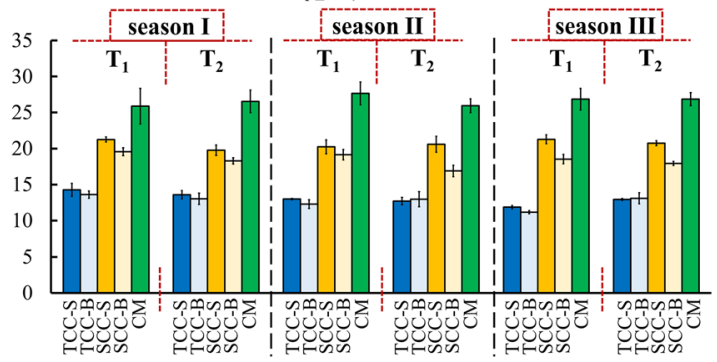

b

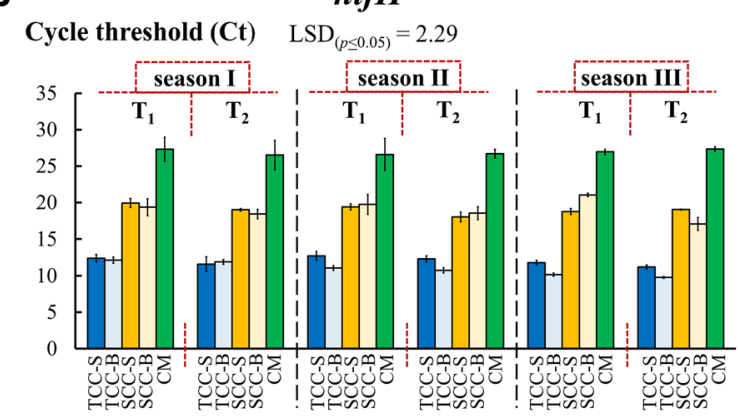

C

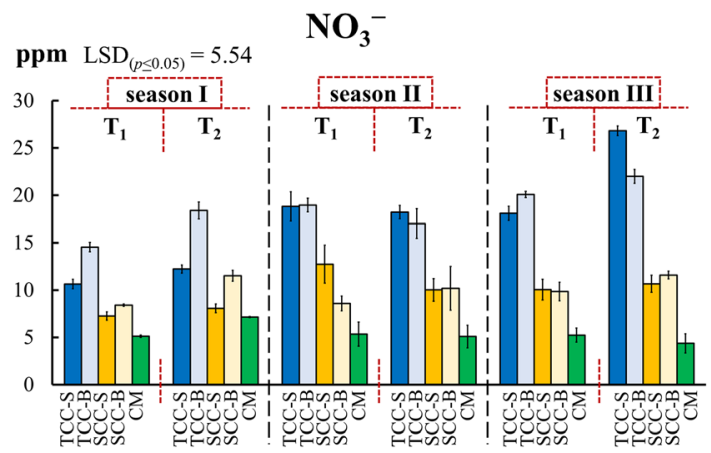

d

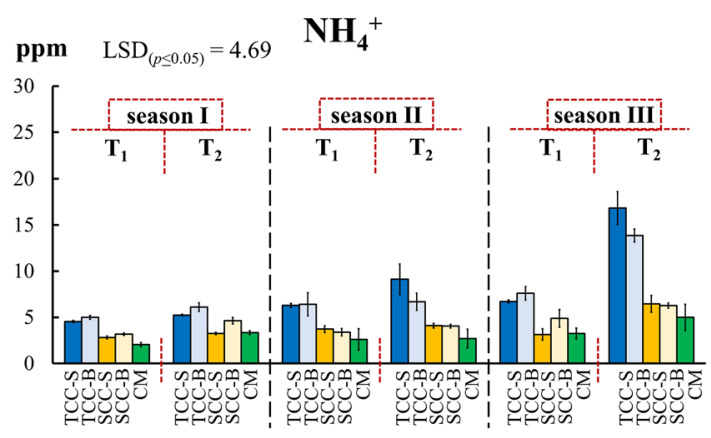

e




4 Fig. 4 a Amount of Nitrosomonas europaea (amoA) and Azotobacter vinelandii (nifH) (b), soil $\mathrm{NH}_{4}{ }^{+}(\mathbf{c}), \mathrm{NO}_{3}{ }^{-}$(d) and their sum $\left(\mathrm{N}_{\mathrm{TOT}}\right)(\mathbf{e})$ in an apricot orchard as affected by cover cropping, season and sampling time. Each bar means \pm standard deviation. LSD interaction was calculated with the Tukey's HSD Test for $p=0.05$. TCC-S: Trifolium subterraneum cover cropping leaving dead mulch on the soil surface; TCC-B: T. subterraneum cover cropping burying dead mulch in the soil; SCC-S: spontaneous flora cover cropping leaving dead mulch on the soil surface; SCC-B: spontaneous flora cover cropping burying dead mulch in the soil; CM: conventional apricot management; season I: 2015/2016; season II: 2016/2017; season III: 2017/2018; T $_{1}$ : March; $\mathrm{T}_{2}$ : June

the other hand, cover crops determine an increase of soil organic matter and organic carbon, which stimulate the microbial biomass and activity. Moreover, each plant species cultivates a specific microbial rhizosphere community thanks to the exudation of secondary metabolites involved in several plant-microorganism interactions such as the legumeRhizobium symbiosis or the association with plant growthpromoting bacteria (Scavo et al. 2019b). In this case, it is reasonable to assume that $T$. subterraneum exudates (e.g. phenols, isoflavonoids) stimulate the amount of $N$. europaea and A. vinelandii. Unfortunately, subterranean clover secondary metabolites involved in this symbiotic association are unknown and their quantity is related to the plant development stage, environmental stress factors and soil characteristics (Scavo et al. 2019b).

\section{Conclusion}

In this research, agronomic, biological and soil microbiology techniques were integrated for the first time to evaluate the effect of subterranean clover cover cropping on the soil weed seed bank and on the amount of soil $\mathrm{NH}_{4}{ }^{+}, \mathrm{NO}_{3}{ }^{-}$and two important bacteria involved in the soil $\mathrm{N}$ cycle. The presence of cover crops, especially $T$. subterraneum, for three consecutive years determined a significant decrease of weed biodiversity and number of seeds in the soil seed bank and, at the same time, a considerable increase of ammoniacal nitrogen, nitric nitrogen and the bacteria $N$. europaea and $A$. vinelandii. These promising results are of key importance for the sustainable management of weeds and fertilization in specialized orchards of Mediterranean agroecosystems, since they allow reducing synthetic herbicides and mineral nitrogen fertilizers and increasing agricultural methods that can have a lower impact on the environment. We believe, in fact, that this approach has its greatest potential in organic farming, where the adoption of chemical inputs is avoided in favour of ecofriendly agronomic practices, such as cover cropping, mainly under an integrated approach. Further research is required on the mechanisms involved in weed control and plantmicroorganism interactions of $T$. subterraneum (e.g. biochemistry of secondary metabolites and symbiotic associations), as well as on the effect of subterranean clover cover cropping on soil chemical characteristics and plant mineral status.

Acknowledgements The authors thank Angelo Litrico for his excellent agronomic assistance during field trials. We are also grateful to the journal's editors and two anonymous reviewers for their useful suggestions.

Author contributions Conceptualization, G.M.; methodology, A.S., A.R., S.L., C.A., G.P., S.F., U.A., and G.M.; investigation and Data Curation, A.S, A.R., S.L., S.F., C.A., G.P., U.A., and A.O.; writingoriginal draft, A.S., A.R., and C.A.; writing - review and editing, A.S., A.R., and C.A.; supervision, G.M.

Funding information This research was realized with the financial support from the University of Catania Project 'Piano per la Ricerca 20162018 - Linea di intervento 2-P5/WP1' (5A722192135).

\section{Compliance with ethical standards}

Conflict of interest The authors declare that they have no conflict of interest.

\section{References}

Adeux G, Vieren E, Carlesi S, Bàrberi P, Munier-Jolain N, Cordeau S (2019) Mitigating crop yield losses through weed diversity. Nat Sustain 2:1018-1026. https://doi.org/10.1038/s41893-019-0415-y

Anderson MJ (2001) A new method for non-parametric multivariate analysis of variance. Austral Ecol 26:32-46. https://doi.org/10. 1111/j.1442-9993.2001.01070.pp.x

Bàrberi $P$ (2002) Weed management in organic agriculture: are we addressing the right issues? Weed Res 42(3):177-193. https://doi.org/ 10.1046/j.1365-3180.2002.00277.x

Bone NJ, Thomson LJ, Ridland PM, Cole P, Hoffmann AA (2009) Cover crops in Victorian apple orchards: effects on production, natural enemies and pests across a season. Crop Prot 28(8):675-683. https://doi.org/10.1016/j.cropro.2009.03.021

Bremner JM (1965) Inorganic forms of nitrogen. In: Black CA, Evans DD, White JL, Ensminger LE, Clark FE (eds) Methods of soil analysis, part 2, Agronomy Monograph, vol 9. American Society of Agronomy, Soil Science Society of America, Madison, pp 11791237

Crooke WM, Simpson WE (1971) Determination of ammonium in Kjeldahl digests of crops by an automated procedure. J Sci Food Agric 22(1):9-10. https://doi.org/10.1002/jsfa.2740220104

Derksen DA, Lafond GP, Thomas AG, Loeppky HA, Swanton CJ (1993) Impact of agronomic practices on weed communities: tillage systems. Weed Sci 41(3):409-417. https://doi.org/10.1017/ S0043174500052127

Enache AJ, Ilnicki RD (1990) Weed control by subterranean clover (Trifolium subterraneum) used as a living mulch. Weed Technol 4(3):534-538. https://doi.org/10.1017/S0890037X00025926

Felix J, Owen MDK (2001) Weed seedbank dynamics in post conservation reserve program land. Weed Sci 49(6):780-787. https://doi.org/ 10.1614/0043-1745(2001)049[0780:WSDIPC]2.0.CO;2

Finney DM, Creamer NG (2008) Weed management on organic farms. The Organic Production Publication Series, CEFS, pp 1-34 
Isik D, Kaya E, Ngouajio M, Mennan H (2009) Weed suppression in organic pepper (Capsicum annuum L.) with winter cover crops. Crop Prot 28(4):356-363. https://doi.org/10.1016/j.cropro.2008.12. 002

Kruidhof HM, Bastiaans L, Kropff MJ (2009) Cover crop residue management for optimizing weed control. Plant Soil 318(1-2):169-184. https://doi.org/10.1007/s11104-008-9827-6

Legendre P, Legendre L (2012) Numerical ecology. Elsevier, Amsterdam

Lemessa F, Wakjira M (2014) Mechanisms of ecological weed management by cover cropping: a review. J Biol Sci 14(7):452-459. https:// doi.org/10.3923/jbs.2014.452.459

Liu Q, Xu R, Yan ZQ, Jin H, Cui HY, Lu LQ, Zhang DH, Qin B (2013) Phytotoxic allelochemicals from roots and root exudates of Trifolium pratense. J Agric Food Chem 61(26):6321-6327. https:// doi.org/10.1021/jf401241e

Livak KJ, Schmittgen TD (2001) Analysis of relative gene expression data using real-time quantitative PCR and the 2(-Delta Delta C(T)). Methods 25(4):402-408. https://doi.org/10.1006/meth.2001.1262

Martínez-García LB, Korthals G, Brussaard L, Jørgensen HB, De Deyn GB (2018) Organic management and cover crop species steer soil microbial community structure and functionality along with soil organic matter properties. Agric Ecosyst Environ 263:7-17. https://doi.org/10.1016/j.agee.2018.04.018

Mauro RP, Anastasi U, Lombardo S, Pandino G, Pesce GR, Restuccia A, Mauromicale G (2015) Cover crops for managing weeds, soil chemical fertility and nutritional status of organically grown orange orchard in Sicily. Ital J Agron 10(2):101-104. https://doi.org/10.4081/ ija.2015.641

Mauro RP, Occhipinti A, Longo AMG, Mauromicale G (2011) Effects of shading on chlorophyll content, chlorophyll fluorescence and photosynthesis of subterranean clover. J Agron Crop Sci 197(1):57-66. https://doi.org/10.1111/j.1439-037X.2010.00436.x

Mauromicale G, Occhipinti A, Mauro R (2010) Selection of shadeadapted subterranean clover species for cover cropping in orchards. Agron Sustain Dev 30(2):473-480. https://doi.org/10.1051/agro/ 2009035

Moonen AC, Bàrberi P (2004) Size and composition of the weed seedbank after 7 years of different cover-crop-maize management systems. Weed Res 44(3):163-177. https://doi.org/10.1111/j.13653180.2004.00388.x

Nair A, Ngouajio M (2012) Soil microbial biomass, functional microbial diversity, and nematode community structure as affected by cover crops and compost in an organic vegetable production system. Appl Soil Ecol 58:45-55. https://doi.org/10.1016/j.apsoil.2012.03.008

Ngouajio M, McGiffen ME Jr, Hutchinson CM (2003) Effect of cover crop and management system on weed populations in lettuce. Crop Prot 22(1):57-64. https://doi.org/10.1016/S0261-2194(02)00111-4

Ohno T, Doolan K, Zibilske LM, Liebman M, Gallandt ER, Berube C (2000) Phytotoxic effects of red clover amended soils on wild mustard seedling growth. Agric Ecosyst Environ 78(2):187-192. https:// doi.org/10.1016/S0167-8809(99)00120-6

Okano Y, Hristova KR, Leutenegger CM, Jackson LE, Denison RF, Gebreyesus B, Lebauer D, Scow KM (2004) Application of realtime PCR to study effects of ammonium on population size of ammonia-oxidizing bacteria in soil. Appl Environ Microbiol 70(2): $1008-1016$

Pignatti S (1982) Flora d'Italia. Edagricole, Bologna

Restuccia A, Lombardo S, Mauromicale G (2019) Impact of a cultivation system upon the weed seedbank size and composition in a Mediterranean environment. Agriculture 9(9):192. https://doi.org/ 10.3390/agriculture9090192
Samarajeewa K, Horiuchi T, Oba S (2006) Finger millet (Eleucine corocana L. Gaertn.) as a cover crop on weed control, growth and yield of soybean under different tillage systems. Soil Tillage Res 90(1-2):93-99. https://doi.org/10.1016/j.still.2005.08.018

Sánchez EE, Giayetto A, Cichón L, Fernández D, Aruani MC, Curetti M (2007) Cover crops influence soil properties and tree performance in an organic apple (Malus domestica Borkh) orchard in northern Patagonia. Plant Soil 292(1-2):193-203. https://doi.org/10.1007/ s11104-007-9215-7

Scavo A, Abbate C, Mauromicale G (2019b) Plant allelochemicals: agronomic, nutritional and ecological relevance in the soil system. Plant Soil 442(1-2):23-48. https://doi.org/10.1007/s11104-01904190-y

Scavo A, Mauromicale G (2020) Integrated Weed Management in Herbaceous Field Crops. Agronomy 10(4):466. https://doi.org/10. 3390/agronomy 10040466

Scavo A, Restuccia A, Abbate C, Mauromicale G (2019a) Seeming field allelopathic activity of Cynara cardunculus L. reduces the soil weed seed bank. Agron Sustain Dev 39(4):41. https://doi.org/10.1007/ s13593-019-0580-4

Scavo A, Restuccia A, Mauromicale G (2018) Allelopathy: general principles and basic aspects for agroecosystem control. In: Gaba S, Smith B, Lichtfouse E (eds) Sustainable agriculture reviews 28 , Sustainable agriculture reviews, vol 28. Springer, Cham, pp 47-101

Scopel E, Triomphe B, Affholder F, da Silva F.A.M., Corbeels M., Xavier J.H.V., Lahmar R., Recous S., Bernoux M., Blanchart E., de Carvalho Mendes I., de Tourdonnet S. (2013) Conservation agriculture cropping systems in temperate and tropical conditions, performances and impacts. A review. Agron Sustain Dev 33(1):113-130. https://doi.org/10.1007/s13593-012-0106-9

Stagno F, Abbate C, Intrigliolo F, Abbate V, Gennari M (2008) Effect of leguminous cover crops on soil biological activity in pots of Citrus unshiu Marcovitch. Ital J Agron 3(3):183-190. https://doi.org/10. 4081/ija.2008.183

Swanton CJ, Shrestha A, Roy RC, Ball-Coelho BR, Knezevic SZ (1999) Effect of tillage systems, N, and cover crop on the composition of weed flora. Weed Sci 47(4):454-461. https://doi.org/10.1017/ S0043174500092079

Teasdale JR, Mohler CL (2000) The quantitative relationship between weed emergence and the physical properties of mulches. Weed Sci 48(3):385-392. https://doi.org/10.1614/0043-1745(2000)048[0385: TQRBWE]2.0.CO;2

Travlos IS, Cheimona N, Roussis I, Bilalis DJ (2018) Weed-species abundance and diversity indices in relation to tillage systems and fertilization. Front Environ Sci 6:11. https://doi.org/10.3389/fenvs.2018. 00011

Vieira MS, Bonilha CL, Boldrini II, Overbeck GE (2015) The seed bank of subtropical grasslands with contrasting land-use history in southern Brazil. Acta Bot Bras 29(4):543-552. https://doi.org/10.1590/ 0102-33062015abb0026

Yeager CM, Kornosky JL, Housman DC, Grote EE, Belnap J, Kuske CR (2004) Diazotrophic community structure and function in two successional stages of biological soil crusts from the Colorado Plateau and Chihuahuan Desert. Appl Environ Microbiol 70(2):973-983. https://doi.org/10.1128/AEM.70.2.973-983.2004

Publisher's note Springer Nature remains neutral with regard to jurisdictional claims in published maps and institutional affiliations. 